\title{
Agnieszka Tes
}

http://orcid.org/0000-0002-9062-441X

Jesuit University Ignatianum in Krakow a.tes@poczta.fm

DOI: $10.35765 /$ pk.2020.3104.14

\section{Silence, Spirituality and Contemplative Experience in Contemporary Abstract Paintings. Analysis of Selected Examples ${ }^{1}$}

\section{AB S T RAC T}

In recent decades, there has been increasing interest in including the spiritual dimension in artistic practice and in discourse on art. This phenomenon seems to be universal but is definitely not homogenic. I examine it by referring to meaningful examples of abstract paintings from different cultural and religious backgrounds. I analyze artworks by two contemporary bicultural painters: the American-Japanese artist, Makoto Fujimura, and American-Iranian artist, Yari Ostovany. The Polish non-figurative artist Tadeusz G. Wiktor is also considered. Their oeuvre can be set within the larger context of great religious and spiritual traditions. I stress the influence of Oriental legacy in contemporary examples of abstract art. I investigate how the selected artworks refer to an invisible reality, and I focus especially on the silence they evoke. My aim is to show how contemporary non-figurative art can influence the viewer by creating a contemplative experience. I also place the selected artworks in the theoretical contexts presented by the artists themselves and refer to classical and contemporary texts.

KEYWORD S : abstraction, painting, spirituality, Oriental traditions, silence, contemplation

\section{STRESZCZENIE}

Cisza, duchowość i doświadczenie kontemplacyjne we współczesnym malarstwie abstrakcyjnym. Analiza wybranych przykładów

Tekst koncentruje się na problematyce duchowości we współczesnym malarstwie abstrakcyjnym. Ten złożony fenomen obecny w sztuce i dyskursie

1 This work was supported by European Funds under grant POWR.03.05.00-00-ZR10/18, realized at Jesuit University Ignatianum in Krakow (Program to strengthen the university's didactic potential for regional development).

Suggested citation: Tes, A. (2020). Silence, Spirituality and Contemplative Experience in Contemporary Abstract Paintings. Analysis of Selected Examples. Perspectives on Culture, 4(31), pp. 207-223. DOI: 10.35765/pk.2020.3104.14. 
krytycznym od wielu dekad można badać w wielu perspektywach. W proponowanym ujęciu uwydatniony został przede wszystkim aspekt ciszy i doświadczenia kontemplacyjnego, przy czym rozważony został on przy uwzględnieniu przenikania się dziedzictwa Wschodu z zachodnią spuścizną malarstwa abstrakcyjnego. Przedmiotem analiz stały się prace dwóch artystów reprezentujących zjawisko dwukulturowości, amerykańsko-japońskiego malarza Makoto Fujimury i amerykańsko-irańskiego twórcy Yariego Ostowany. Następnie kieruję uwagę na wybrane, najnowsze prace wybitnego polskiego abstrakcjonisty Tadeusza G. Wiktora, zestawiając je z wcześniej omawianymi dziełami. Artykuł rozpoczyna się od syntetycznego szkicu ukazującego zagadnienie duchowości i koncepcje ciszy w malarstwie niefiguratywnym. Kolejne części poświęcone są poszczególnym artystom, których twórczość zostaje osadzona zarówno w kontekście kulturowym, jak też religijno-duchowym. W dwóch branych pod uwagę przypadkach wskazuję na oddziaływanie orientalnych inspiracji wynikających z pochodzenia twórców. Głównym celem artykułu jest ukazanie, w jaki sposób analizowana sztuka oddziałuje na odbiorcę poprzez wytworzenie doświadczenia kontemplacyjnego oraz uzmysłowienie wartości ciszy w otoczeniu kulturowym współczesnego człowieka. Tłem rozważań są wypowiedzi samych twórców oraz klasyczne i najnowsze propozycje podejmowane w literaturze przedmiotu.

SŁOWA KLUCZE: abstrakcja, malarstwo, duchowość, tradycje orientalne, cisza, kontemplacja

\section{Introduction}

With the proliferation of virtual reality and the crisis in symbolic thinking, is it still possible to refer to an immaterial, transcendent reality in painting in this age of secularization and consumerism? Has postmodernism eliminated the artist's urge to create visible traces of the spiritual-something that is beyond simulation or ironic distance? This article will focus on the spiritual aspects of contemporary abstract painting and is meant as a contribution to a larger piece of research. First, I will discuss the presence of spirituality in contemporary art; in particular, I refer to the concept of silence in abstract painting. In the main section of the text, I investigate how a selection of contemporary, non-figurative artworks refers to an immaterial, invisible reality, and how they engage artistic tools to evoke spirituality. I am also interested in how they connect with the artist's identity. I aim to show how non-figurative art can influence the viewer by creating the experience of contemplation. To focus on this, I have selected three meaningful examples from different cultural and religious backgrounds in order to show that although this phenomenon has universal value, it is definitely not homogenic. I will analyze artworks by two 
contemporary bicultural painters, the American-Japanese artist, Makoto Fujimura, and the American-Iranian artist, Yari Ostovany, and also by the Polish abstract artist, Tadeusz G. Wictor. Each of these painters I refer to enlists spiritual references in their oeuvre and their approaches are consistent in this respect. They represent different but not opposing approaches to abstraction and they are definitely serious about discovering the spiritual potency of the image, in contrast to the highly widespread tendency to treat the image as a double-coded play or mere manifestation of painterly skills. What they share, although adapted in various ways, is the influence of Abstract Expressionism. I hope the proposed selection will highlight my observations and thereby strengthen the main points of the article; in this sense, these works will be representative, even if the phenomenon I focus on is more diverse and complex.

\section{Spirituality in Abstract Painting-General Remarks}

Contemporary art, whose multitudinous tendencies are often linked to secularly orientated mechanisms of institutional and commercial function, is rarely considered in terms of its spirituality. However, in recent decades it has been possible to observe an increasing interest in including the spiritual dimension in artistic practice and discourse. This process has manifested in international exhibitions and published books and articles that discuss this issue, such as Jungu Yoon's Spirituality in Contemporary Art. The idea of the Numinous (2010), Charlene Spretnak's The Spiritual Dynamic in Modern Art (2014) and Encountering the Spiritual in Contemporary Art (Fanning, 2018). Charlene Spretnak (2014, p. 9) claims that the turn of the millennium sparked a temporary uptick in spiritual allusions in culture. This would still appear to be the case, even if its impact is less noticeable today.

Since its beginnings in the first decades of the $20^{\text {th }}$ century, abstract painting has had an international quality related to the universal language it created - a language that went beyond personal perceptions or views of the sensual world. At the same time, it developed in different directions with contrasting purposes (Barr, 1986, p. 19). Even if modernist interpretations of non-figurative art attempt to reduce it to its formal dimension, the spiritual roots of abstract art are now very well recognized and appreciated (Ringbon, 1966; Tuchman, 1986). The spiritual tendency in abstract painting that was initiated by its pioneers, Wassily Kandynsky, Kazimir Malevich and Piet Mondrian, was a temporary trend that branched into various currents after the Second World War. Each of these had their own roots that were often different from the esoteric, theosophical doctrine that 
had dominated previously. French artists such as Roger Bissière and Alfred Manessiere included a Christian context in their abstract artworks. Generations of American Abstract Expressionists, including such acknowledged artists as Mark Rothko, Barnett Newman, Ad Reinhardt, and also the rarely mentioned Leon Berkowitz, revealed the potential of non-figurative art to pursue a contemplative quality in painting. In these instances, creative impulses were often related to Jewish or Christian mysticism, or an interest in Eastern traditions. Painting was no longer just an object placed on a wall to be seen; it became a phenomenon that creates an immersive environment, thereby involving a relationship between art and viewer.

\section{Concepts of Silence in Abstract Painting}

Donald Kuspit maintained that "authentically spiritual abstract art does not so much 'communicate' as 'induce an attitude of communion and contemplation"” (Kuspit, 1986, p. 314). The important aspect that emerges from the contact with large canvases by American abstractionists is the feeling of silence that emanates from the of presence of their artworks. This deliberate silence, expressed by Kuspit (1986, p. 314) as deliberate negation, "is a major way of sustaining the elusive spiritual atmosphere of the abstract work by ruthlessly reducing the artistic [...] to an absolute minimum. Indeed, silence attempts to eliminate beauty altogether. Paradoxically, the absolutely silent becomes radically beautiful [...]" (Kuspit, 1986, p. 314).

However, silence in non-figurative paintings also has connotations that are less positive. In theological terms, it is referred to as 'kenosis': the apparent relinquishment of skills, an emptying out of form, with silence becoming dangerously close to the emptiness of the formalist approach (Fuller, 1983, p. 145). On the other hand, Gilber-Rolfe points out that the situation today has changed because the emptiness that is evoked in painting is also widespread in the world of technology "in an endless stream of empty surfaces.” By using the term 'blankness,' he also emphasizes that it is of a different nature to silence, which can be interpreted in a more poetic way. Moreover, blankness "once marked the absence of the sign by being a sign for absence, it is now the sign of a ubiquitous technological presence" (Gilbert-Rolfe, 1999, p. 113). When discussing silence/emptiness in abstract painting, one should also maintain that emptiness can be associated with a formalist approach, but it can also have deeply spiritual associations that are in fact in opposition to this formalistic line. Depending on the artist's worldview, such emptiness can connote certain aspects of negative theology or Buddhist emptiness. In this case, painting does not affirm 
the existence of a spiritual realm by artistic means but refers to the complete impossibility of reaching this realm, and thus the invisible is treated as invisible. The artwork then becomes a specific challenge that, in some cases, can act as a threshold where all cognitive faculties are suspended. The comparisons with via negativa that are present in Western and Eastern religious traditions seem to be appropriate here (Lipsey, 1997, pp. 332334). Moreover, silence or emptiness in abstract painting can be juxtaposed with the preliminary stage of many spiritual and meditative practices by which the seeker attempts to empty her/his mind of all thoughts, imaginings and distractions. This relationship between spiritual practice and abstract art was discussed by Sixten Ringbom (1986, pp. 132-134) in one of his classic texts on spirituality in early abstract art. In this text, art historian refers to the formless state prescribed in various spiritual traditions as an interesting background for the analysis of non-figurative painting.

Today, despite being able to observe changing cultural and civilizational conditions, in abstract artworks one can still see the presence of silence in relation to transcendental, spiritual or poetic associations. Often, it is linked to the sphere of beauty. The painters I refer to appear to be conscious of the impact of technologically advanced images and have managed to escape the effects of blankness and the similarities of artificial reality to create metaphysical associations. 'Silence' is definitely a more appropriate term to ascribe to these artworks than 'blankness,' which has more pejorative associations. I will further my argument by analyzing selected examples and discussing the various contemplative aspects of silence that they evoke. What needs to be stressed here is the fact that for the artists I focus on, the spiritual dimension of their art is still vital and uncompromising; it sustains the very core of their oeuvre and cannot be reduced to a mere formalistic device. This view will be discussed within a larger framework, which will include an examination of the influence on the viewer of metaphysically orientated abstract painting.

\section{Makoto Fujimura: Testimony of Faith}

Makoto Fujimura, an internationally recognized American painter, writer, and speaker with Japanese roots, could be considered a contemporary successor of Abstract Expressionism, which he combines with his Japanese sense of the world and his experience in traditional Japanese art. The uniqueness of his approach derives from juxtaposing non-figurative forms with techniques inspired by Nihonga (literally 'Japanese-style paintings'), which he studied at Tokyo National University of Fine Arts and Music. To create his luminous abstract paintings, he uses ground pigments made 
from minerals, shells, coral and semi-precious stones. Another feature distinguishing Fujimura is the strong relationship between his art and his religious identity. The testimony of this painter indicates that his Christian faith, which is inseparably linked to his artistic attitude, has particular implications:

I have noticed, as an artist with a Christian faith, that if we are explicit about our faith in the public sphere-if we even mention our commitment to live a Christian life-we are dismissed right away in the art world [...] To invoke the transgressive, the cynical, the elusive may be the only way to become a respected artist; needy, shock-filled, ironical work gets attention as 'serious' (Fujimura, 2016, p. 47).

When analyzing Fujimura's art, one should take into consideration his statements, which have obviously led to spiritual interpretations of his oeuvre. The titles of his works and his own comments on his artworks with Christian content give them special depth and influence their reception. As an examplar, I chose the triptych Silence Mysterion (2017) as this painting embodies the discussed theme of silence. The painter's website explains that the word 'Mysterion' is a Greek word that was used when St. Paul spoke of the 'mystery of the Gospel' (Ephesians 6:19). Fujimura worked on this painting during a particular period in his life which included the passing of his father, Osamu Fujimura, who was a pioneer in Acoustic research. He recalls, "I have trouble remembering painting this image, due to the darkness that suddenly enveloped me with compounding losses." ${ }^{2}$ His previous Silence series was also related to suffering. It was inspired by the trauma of the persecution of Christians in seventeenth-century Japan, as described in Shasaku Endo's novel Silence, (subsequently made into a film by Martin Scorsese). As the painter stated, this series explored the hidden dimension of beauty-born of sacrifice - that appeared within the trauma and suffering associated with faith. Beauty has specific connotations in Japanese culture. Natural beauty overlaps with sacrifice-decay with permanence, death with life. As the artist asserts, "The aesthetic link between beauty and sacrifice may be the reason that the Japanese could plumb the Christian gospel's narrative of sacrifice and redemption" (Fujimura, 2016, p. 65). This series sought to honor his father's legacy by exploring themes related to the speech and hearing sciences. "Depicting silence is also to depict what we »hear « through silence, to visually capture the »soundwaves « of silence." ${ }^{3}$ This statement could also be applied to the triptych Silence Mysterion,

2 https://www.makotofujimura.com/works/ (access: 13.12.2020).

3 https://www.makotofujimura.com/works/ (access: 13.12.2020). 
in which silence is not monolithic but vivid, potentially full of meaning and feeling, and thus shapes the viewing process. It depends on the spectator's sensibility, personal background and interpretative abilities as to what would be 'heard through the silence.' It is as if 'soundwaves of silences' act upon the viewer's eye in dynamic but subtle penetrations of an invisible realm, creating the space for many kinds of interactions. As the title indicates, the mystery of silence alluded to here is the Gospel, and this implies a spiritual message of Revelation. Furthermore, as the painting was created at the time of the passing of his father, it may express a certain kind of metaphysical suffering and hope. The Triptych is composed of layers of minerals that create subtle interplays in tones of blue, which are emanating and changing in their intensity from saturation to transparency. Changing tones of color can be compared to acoustic vibrations or to breathing dynamics as they have a characteristic airy quality. Blue has widely known spiritual connotations, as was also stressed in twentieth-century art theory. Kandynsky (1996, p. 88), in his famous Concerning the Spiritual in Art (1910), describes blue as a heavenly color. Turning in upon its own center, it retreats from the spectator and has associations with infinity, calmness, purity and transcendence. In Fujimura's artwork, blue-with its palette of soft tones that are only rarely disturbed by stronger and darker touches of paint_-inspires contemplation. However, this contemplation can be called 'active' as it gradually reveals more and more of the internal depth of the artwork. When describing the creation of this painting, the artist mentioned three 'eyes' or 'stigmas' that suddenly appeared on the leftmost panel. ${ }^{4}$ They do not reveal themselves immediately to the spectator but may be discovered only after one allows oneself to be lost in the interactions of color. Are the darker and more expressive fragments on the luminescent background the marks of pain, the 'stigmas' of suffering inherent to death and Christian identity? Contemplation of the artwork becomes spiritual contemplation. One must empty one's mind of external impulses in order to be able to participate in this 'silence mysterion;' but at the same time, the artwork enhances this kind of purification. Referring to this process, which seems to be a characteristic trait of Fujimura's art, the painter comments:

The surface of my 'slow art' is prismatic, so at first glance the malachite surface looks green. But, if the is allowed to linger on the surface-it usually takes ten minutes for the eye to adjust - the observer can begin to see the rainbow created by layer upon layer of broken shards of minerals. Such a contemplative experience can be a deep sensory journey towards wisdom (Fujimura, 2016, p. 20).

4 https://www.makotofujimura.com/works/eye. 
In Fujimura's art, we do not observe "reducing the artistic [...] to an absolute minimum" (Kuspit, 1986, p. 314). Silence does not attempt to eliminate beauty altogether. Rather, as the title of Fujimura's book indicates, silence and beauty perform together in a mutual relationship. The artist achieves a different quality of silence to that present in artworks by Malevich, Newman, Rothko, and in monochrome paintings. When compared to these, rather than having an intense presence, Fujimura's painting seems much more fluent, light, open, and dynamic. The large, horizontal Silence Mysterion triptych seems to encompass the viewer's perception, as is characteristic of environmental arrangements in contemporary art. This special, painterly technique produces the impression of refraction and the elusiveness of airy or rather heavenly space, as it alludes to the mystery of Christianity. It is obvious that Fujimura does not relinquish the possibilities of painting to transform matter into something more than a visual experience. His artwork is not like the blank digital image that is empty of human sensitivity and touch or is a mere demonstration of virtuosity. This American-Japanese painter celebrates beauty as a means to evoke an invisible reality which is not only of an aesthetic but also of a spiritual and ethical nature. His personal experience has led him to connect art with Christian content, the mystery of Christ, and with the human ability to reflect the gratuitous gifts of The Creator God (Fujimura, 2017, pp. 51-55). Even though beauty, which is part of the famous Platonic Triad, was neglected in the course of contemporary art, for Fujimura it is definitely not something to be ignored. On the contrary, in some of his texts this artist, who also adopted a role of cultural influencer, appreciates the significance of beauty for physical, mental and spiritual health.

This American-Japanese painter's attitude toward the relationship between religion and art is affirmative and serious. He develops unusual, poetic ways of transposing Christian Revelation into visual language by adopting a subjective sensitivity towards issues of belief. At the same time, he inspires the viewer to discover a similar path by contemplating his artworks. His references to religion are not literal; they do not contain widely known systems of symbols, but they express a personally internalized faith. Fujimura stands in opposition to the widespread tendency described in James Elkins' (2004, p. 47) book On the Strange Place of Religion in Contemporary Art, where there is no place for sincerity and the only accepted attitudes toward religion in the art world include critical distance, ambiguity, irony, and camouflage. 


\section{Yari Ostovany: Painting and the Numinous}

In the work of the contemporary American-Iranian painter, Yari Ostovany, there is also a meeting of two different cultural backgrounds that brings forth unique artistic effects. In this case, Iranian heritage meets the sensibility that is present in Western art. The artist declares:

Living in the space between two cultures, I have always been interested in investigating the nomadic in-between spaces [...]. I have always been further interested in the mechanics of a symbiotic relationship between Persian and Western Art; the former being my innate orientation and the latter the tradition in which I have been trained. ${ }^{5}$

Inspiration is taken from Sufi mysticism and poetry, but also from Zen Buddhism and Western culture, from Abstract Expressionism, music (Bach, Beethoven, jazz, world music), philosophy, and poetry. Even if the religious context here differs from that of Fujimura, the concept of using abstract painting to express spiritual depth seems to be comparable. As in Fujimura's art, beauty seems to be of great importance here and, similarly, it is not considered only within the sphere of the aesthetic. Rather, beauty is seen to be a reflection of the insight and effect of the mysterious process of creation, where the superficial effects of prettiness should be abandoned to reach a more quintessential level. Also in this case, artistic skills are not 'reduced to an absolute minimum' and the form is not ascetic. On the contrary, painterly technique is refined and developed into a complicated process, thus engaging with the spectrum of the various, individually employed possibilities that painting offers. The artist states:

Often starting with calligraphic gestural marks, solid forms which then dissolve as the layers explode and implode, are added, rubbed out, re-applied, scoured into and scraped away. Going back and forth until another dimension-a sense of resonance-arises, when the whole becomes greater than the sum of its parts, where forms and marks become metaphors for a transcendent reality. ${ }^{6}$

I have chosen to focus on and analyze the contemplative experience that the Numinous series attempts to provoke. The idea of the numinous is present in contemporary discourse on art. Jungu Yoon, for example, discusses it in relation to the concepts of Rudolf Otto, Mircea Eliade

5 https://kayhanlife.com/culture/art/artist-yari-ostovany-exhibits-in-la-explores-art-of-east-and-west/ (access: 13.12.2020).

6 http://www.yariostovany.com/statement/index.html (access: 13.12.2020). 
and C.G. Jung. He reveals that there is disagreement as to the origins of the concept. In the Concise Oxford Dictionary, numinous is linked to the Latin word numen, which is variously translated as nod, command, will, consent, inspiration, divine will, divine power, divinity, deity, godhead, divine majesty, god and goddess. As indicated elsewhere, this is based on the Greek word neuma, which signifies the manifestation, will or power of a divinity (Yoon, 2010, p. 25). One of the most famous understandings of the concept of the numinous comes from Rudolf Otto's The Idea of the Holy: An Inquiry into the Non-rational Factor in the Idea of the Divine and its Relation to the Rational. Here, the numinous indicates the presence of a non-rational mystery behind religion which is both awesome (mysterium tremendum) and fascinating (mysterium fascinans), revealing or suggesting the presence of a living God and inspiring awe and reverence. This kind of phenomenon originates from the outside but is experienced and felt within. Rudolf Otto enumerates many elements associated with the numinous, e.g. urgency, energy, vitality, passion, force, movement, excitement, activity, impetus (Otto, 1959, pp. 23-24). Although Otto is especially focused on Christianity, he admits that the numinous manifests in all mainstream religions. Both Jung and Eliade built on Otto's idea of the numinous, but their concepts took different courses (Yoon, 2010, pp. 26-30). Jung's ideas, for example, concern the exploration of the psyche, which-in contrast to Otto's concept-is not confined to religious discourse but embraces humanistic, secular and scientific worldviews.

Rather than strictly referring to only one concept, Ostovany assumes a broad view on the question. In his commentary on his own website, Ostovany alludes to the numinous as evincing the presence of a deity or spiritual presence, whereas his more general statements indicate his interest in the crossing point of the unconscious, the personal and the collective. As frequently happens in Ostovany's oeuvre, The Numinous series includes paintings created over a long period of time, from 2003 to the present day. Many of his artworks are simply entitled Numinous, directly referring to the phenomenon, but in other cases the titles of the canvases included in the series allude to related issues from various religious and spiritual traditions, e.g. The Bodhi Tree, The Oracle, Night Pilgrim, Cathedral, Altar, The Multitude of Angels, the Stone of Amunadara, Arjuna's Lament, The Poet, and The Alchemist. Here, atmospheric abstraction, as the artist calls it, alludes to the Transcendental and represents a mystery that rarely occurs in normal conditions. What are the artistic tools used to evoke such an awesome spiritual sensation? How does the artist approach this liminal experience? What is striking at first sight is a lyrical, dreamlike quality of color composition that is comprised of rare tones juxtaposed in a sophisticated manner. This is built layer upon layer, attaining translucent effects and vague metaphysical 
associations that are grasped intuitively rather than intellectually. Sometimes, contrasts of colors are exposed to strengthen the opposition between dark and light; however, he never chooses obvious artistic solutions. Tones and shades seem to be prepared as though through an alchemical process that gives them exceptional resonance. American-Iranian artist uses an oily technique that enables a lot of experimentation. The painterly matter seems to be glowing, invigorating, sometimes as if involving a mixture of elements and sometimes as though made of cosmic dust. Ostovany dramatizes compositions by letting the process of their creation be spontaneous, stressing the contrasts and alternating the textures. For the spectator, it is like an encounter with an unexpected phenomenon that evokes an unknown realm. In some canvases, the luminosity is almost blinding, but at the same time it provokes the feeling of a warm, transcendental presence that is comparable to the description of mystical experiences in the various paths frequently referred to by the painter. The light has no empirical nature or external source, but is, as Ostovany affirms, "an intimation of Lux Aeterna, self-generating light." 7 This universal archetype is evoked in an expressive way by the artistic process that seems to penetrate something of the intangible essence of light. The viewer is invited to dive deep into internal, metaphysical landscapes whose special artistic quality evokes transcendental silence related to a numinous experience. It is attained by various means: using a horizontal divide beyond which infinite, imaginary space ranges, or by artistically alluding to mystery or the sublime. For example, some parts are brighter in a way that suggests hidden sources of luminescence or unusual nuances of light that shine through transparent veils, as if indicating the existence of an invisible dimension. As with Fujimura's artwork, silence here has vivid potential. However, in contrast to the previously analyzed painting by the Japanese artist, it seems to emerge, evoking unexpected sensations rather than encompassing sight by its subtle presence. The spectators' experience could be compared to witnessing the sudden and overwhelming appearance of something of a supernatural character. Large areas of color, juxtaposed with denser and more dynamic fragments, work as contrary aspects in a mutual interplay-silence and agitation, light and matter, unseen and manifest, higher order and chaos. It can also be interpreted in a metaphorical way, engaging the unconscious and emotional side of the viewer. Like Fujimura, Ostovany stimulates contemplation as a dynamic process that is open to astonishment, awe and delight, and in this respect, he is far more intense. In this context, contemplation implies a sacred 'dread' or a holy awe which is stimulated by a work of art. The artist seems to be especially sensitive to the moment of

7 http://www.yariostovany.com/statement/index.html (access: 13.12.2020). 
revelation, when the invisible reality surpasses the level of common experience. These moments of revealing mystery - when intuition of a higher order is attained are frequently re-presented in this oeuvre when the painter refers to mystical encounters, poetic or musical ecstasy, sudden illumination, a mysterious voyage or sacred spaces. Ostovany traces these motives throughout age and place, from ancient times to now, from the East and the West, calling upon sacred stones and trees, cathedrals, altars, and oracles. In a way, this attitude could be symptomatic of a nomadic spirituality; it is also characteristic of a broader approach that is able to acknowledge the sacred dimensions present within various religious paths and human experiences, as was so impressively developed in Mircea Eliade's writings. It is worth referring to Eliade's essay The Sacred and the Modern Artist, in which he recognizes that modern art is susceptible to religious interpretation by two specific characteristics - "the destruction of traditional forms and fascination of the formless" (Eliade, 1985, p. 83)—which is true of both Ostovany's and Fujimura's art. However, in their art we do not see 'the hierophanization of matter' that is typical of 'cosmic religiosity' and which is present in examples studied by Eliade. Matter seems merely to play the role of a vehicle that evokes the transcendental, and thus the immanence of matter is overcome. Even if Ostovany's Numinous series could be interpreted by calling upon the sublimity of the cosmos and his artworks could be compared to space, as depicted in the images of the Hubble telescope (as the artist remarks on his website), the religious cannot be reduced here to its merely cosmic dimension. Behind it stands reality, as witnessed in mystical experience. Both painters analyzed here re-establish art as a privileged place of contemplation, a refuge from the chaotic mass of contemporary life with its expansion of virtual simulacra. In this sense, it stands in opposition to the tendency described in The End of Art by Donald Kuspit (2005): art no longer negates beauty or adapts a nihilistic pose. On the contrary, it arises from a metaphysical sense, intuited by the painter through its manifestation in the artwork, and back to a metaphysical sense that is revealed in the painting to the viewer. The final example will pursue this analysis.

\section{Tadeusz G. Wiktor: Light and Transcendental Silence}

In contrast to the first two instances, the abstract paintings of the Polish artist Tadeusz G. Wiktor are developed within a geometric language. One of the most outstanding representatives of this form of abstraction in contemporary Poland, he very individually refers to the legacy of the suprematism of Kasimir Malevich and the color field painting of Mark Rothko, creating not only his own visual language but also an original art theory. The first 
transcendental references in Wiktor's oeuvre appeared in the 1970s, and in some respects they may be regarded as a psychological reaction to the oppression of the communist system. Since then, the painter has combined his artistic and spiritual searching, being especially inspired by Jung's concepts of archetypes and symbols, as well by the idea of individuation. Other sources include Christian and Gnostic literature, as well as the spiritual classics of the West and East and perennial philosophy. In Wiktor's artistic theory, the act of creation is compared to meditation and is considered a way of experiencing the Absolute. Thus, the artwork is seen to be the result of an endeavor to overcome conditioned and changing phenomena with transcendently orientated states that are unified with painterly practice. Inspiration derives from dreams and the universal language of archetypal symbols such as crosses, circles and squares, triangles and cones, the horizon, gates, positive and negative, walls, white and black (Wiktor, 1994, p. 16). The author formulated his own concept of artwork as icon, which differs significantly from orthodox doctrine, in which figurative icons refer to the Incarnation of Christ. Here the only fundamental condition that any artistic realization must fulfill to become an icon is that it is rooted in an elementary and common experience of sacrum (Wiktor, 1994, p. 63). Abstract icons are intended to reveal an invisible but existent spiritual reality and, as such, they indicate a transcendental sphere behind them. They do not end up only attracting spectator's gaze. When approaching the problem of their reception, the artist proposes insight, which implies going beyond normal sensual perception (Wiktor, 1994, pp. 61-62). In many of his series, for example Passages, Prayers, Lublin Iconostasis, Gates, Wiktor apparently relinquishes his painterly skills by ruthlessly reducing the artistic to an absolute minimum. Indeed, it seems that the words by the American art critic Kuspit are perfectly appropriate to these examples: "Silence attempts to eliminate beauty altogether. Paradoxically, the absolutely silent becomes radically beautiful [...]" (Kuspit, 1986, p. 314). However, Wictor does not limit himself to such an attitude as he avoids the dangers of formalism. For example, in the Icons series he started in 1992, he returns to a more subtle painterly technique that evokes luminosity and spiritual beauty. The same can be said in reference to his most recent artworks which will be analyzed here. In these pieces, the artist uses geometrical forms - especially circles and squares-for their archetypal connotations. For Wiktor, they act as mystical symbols of Wholeness. The composition of the paintings from the series entitled Light for... is centrally arranged by the juxtaposition of two canvases, a square within a square alluding to the famous suprematist work of Malevich. Their impact is due to their monumental simplicity and the artist's way of operating within a reduced color palette. The artist returns here to 'luminous painting.' As Wiktor states, for him: 
The most inspiring sources for creating 'luminous paintings' are the illuminations that appear in dreams. These images have an unfading epiphanic power $[\ldots]$. What intrigues, attracts and meditatively activates me is the koan-like, paradoxical and oxymoronic character of the medieval Latin sentence Lux umbra Dei-Light is a shadow of God. The hermeneutics of this koan confirm my Gnostic intuition: sacral light is not an image of God; it is His reflection, his manifestation, His shadow. If this manifestation is given us in 'spiritual sight', it does not mean that we saw God, but that we have experienced His existence (Stano \& Daca, 2019, p. 122).

The latest canvases introduce a luminous effect by evoking the veiling and revealing of a mysterious presence of supernatural light. In contrast to the previously analyzed artworks, there is a deep feeling of transcendental silence that is static and creates a certain challenge to perception. This effect is intensified by the fact that the painter renounces any kind of expression in order to pursue a more disciplined, meditative process of creation and technical perfection. Wiktor's light compositions refer to the impossibility of adequately representing the highest realm, which is why he employs certain means that correspond to this aporia. In the series of paintings entitled Light for Boziena, which is dedicated to a prominent Polish art critic, luminosity emerges from a gradation of cobalt blue where the central motif of a circle of light is obscured by the presence of a square at the front that evokes the threshold of our cognition. A mysterious deep blue light seems to emanate or slightly pulsate with an inner energy that is, perhaps, an echo of the emanating presence of an orthodox icon. Characteristically, the effect of light is reached in profound, rather dark tones that intensify these supernatural associations. It is not so much a simple opposition of light and darkness as a gradual passage which seems to soften and calm the sight. Tones of blue create a feeling of metaphysical distance. At the same time, the presence of the artwork in the field of view is very strong, similar to the presence of an abstract icon which does "not so much 'communicate' as 'induce an attitude of communion and contemplation”" (Kuspit, 1986, p. 314). An analogous formal solution is proposed in the artwork Lux Umbra Dei, in which two juxtaposed squares are penetrated by an interplay of light ranging from light to darkness. In this case, the central darkness seems to guard the mystery, as though recollecting the title of the famous spiritual classic, 'The Cloud of Unknowing.' These images are not only inspired by spiritual epiphany but also create an intense metaphysical resonance. The viewer is placed in the presence of the demanding silence of the Invisible, which cannot be represented in any artistic language. The silence here can be connected with emptiness, as understood in a spiritual way. The use of simple geometrical compositions, the lack of expressive traces, the influence of calm gradations of color and their meditative quality can induce an attitude 
of emptying or purifying the mind and directing it toward the transcendent. In this sense, it can be compared to the conditions that are indispensable at the initial stages of spiritual practice, when the seeker should empty himself of presuppositions, expectations, and habitual ways of perceiving. One can also see a parallel between the paradoxical compositions of light here with paradoxes present in descriptions of mystical experience and in negative theology, where all human descriptions of God must be suspended. In this context it is worth citing, for example, Thomas Merton's reference to St. John of the Cross's prescription:

Learn the tremendous value of this obscure and sometimes crucifying light of faith, which darkens and empties your mind with respect to all natural conviction and leads you into realms without evidence in order to bring you to the threshold of an actual experimental contact with the living God (Merton, 2004, p. 95).

It should be stressed that the contemplation enhanced by abstract artwork has a different character to that of a strictly religious contemplation, which does not demand that art acts as a mediator. As already stated, however, certain metaphysically orientated abstract paintings create a space that is conducive to contemplation: not only an aesthetic kind, but also leading toward a spiritual experience or even to prayer. The effect of spiritual practice overcomes the discursive level, as is the case with paintings of this genre. Jean-Jacques Wunenburger (2011, p. 200) remarked: "looking at such (abstract) paintings seems to be an activity by which the subject tries - in a non-conceptual way - to become co-present to a certain transcendental truth". This is the case with all of the artworks I have focused on, but in Wiktor's painting this tendency reaches its most radical fulfillment. The artist himself compared the act of painting with praying to the Absolute. His latest canvases, which are the synthesis of a long artistic journey, act as contemplative tools that strongly focus the consciousness of the spectator-purified from external distractions and directed into metaphysical realms.

\section{Conclusion}

It is worth underlining that the meeting of East and West in the context of abstract art creates unique possibility of communication based on silence. In all of the examples analyzed here, the evocation of silence is strictly associated with the spiritual dimension and with the realm of beauty, which has transcendental status in its classical exegesis. The painters I have referred to re-establish art as a place of contemplation-a witness 
of the Transcendental in opposition to widespread secular artistic trends more concerned with our immediate reality. Their oeuvre can be set within a larger context of great religious and spiritual traditions. They are representative of a still-developing tendency that seeks to express a need to return to the sacred dimension in art that was always present, in defiance of attempts at its elimination. Within this framework, many individual artistic approaches are possible, but there is also a universality of visual language that makes this art more accessible to a wider public. Thus, the gallery can become a place for contemplation and an encounter with essential questions. This process also restores the dignity of the painting and its viewer by reminding us of dimensions that have been diminished by a more materialistic worldview dominant in contemporary culture.

\section{References}

Barr, A.H. (1986). Cubism and Abstract Art. New York \& Cambridge, MA.: The Museum of Modern Art \& The Belknap Press of Harvard University Press.

Eliade, M. (1985). Symbolism, the Sacred, the Arts. New York: Continuum.

Elkins, J. (2004). On the Strange Place of Religion in Contemporary Art. New York \& London: Routledge.

Fanning, L.K. (Ed.). (2018). Encountering The Spiritual in Contemporary Art. New Haven \& London: Yale University Press.

Fujimura, M. (2016). Silence and Beauty. Downers Groove: IVP Books.

Fujimura, M. (2017). Culture Care. Downers Groove: IVP Books.

Fuller, P. (1983). Art and Psychoanalysis. London: Writers and Readers.

Gilbert-Rolfe, J. (1999). Beauty and the Contemporary Sublime. New York: Alworth Press.

Kandynsky, W. (1996). O duchowości w sztuce [Concerning the Spirirual in Art] (S. Fijałkowski, Trans.). Łódź: Państwowa Galeria Sztuki.

Kuspit, D. (1986). Concernig the Spiritual in Contemporary Art. In M. Tuchman (Ed.), The Spiritual in Art: Abstract Painting 1890-1985 (pp. 313-325). Los Angeles \& New York: Los Angeles County Museum of Art \& Abbeville Press.

Kuspit, D. (2005). The End of Art. Cambridge: Cambridge University Press.

Lipsey, R. (1997). An Art of Our Own. The Spiritual in Twenttieth-Century Art. Boston \& London: Shambala.

Merton, T. (2004). The Inner Experience. Notes on Contemplation. New York: Harper One.

Otto, R. (1959). The Idea of the Holy; an Inquiry into the Non-rational Factor in the Idea of the Divine and its Relation to the Rational (J.W. Harvey, Trans). Harmondsworth: Penguin Books. 
Ringbom, S. (1966). Art in the Epoch of Great Spiritual Occult Elements in the Early Theory of Abstract Painting. Journal of the Warburg and Courtauld Institutes 29: 386-418.

Ringbom, S. (1986). Transcending the Visible: The Generation of the Abstract Pioneers. In M. Tuchman (Ed.), The Spiritual in Art: Abstract Painting 1890-1985 (pp. 131-153). Los Angeles \& New York: Los Angeles County Museum of Art \& Abbeville Press.

Spretnak, Ch. (2014). The Spiritual Dynamic in Modern Art. New York: Palgrave Macmillan.

Stano, B. \& Daca, A. (Eds.). (2019). Metafizyka obecności. Inspiracje religijne w dzietach artystów krakowskich 2000-2019 [Metaphysics of Presence. Religious Inspirations in Artworks by Krakow Artists 2000-2019]. Kraków: Uniwersytet Pedagogiczny.

Wiktor, T.G. (1994). Teksty artystów. Tadeusz Gustaw Wiktor [Texts of the Artists: Tadeusz Gustaw Wiktor]. Kraków: QQPress.

Tuchman, M. (Ed.). (1986). The Spiritual in Art: Abstract Painting 1890-1985. Los Angeles \& New York: Los Angeles County Museum of Art \& Abbeville Press.

Wunenburger, J.-J. (2011). Filozofia obrazów [Philosophy of Images] (T. Stróżyński, Trans). Gdańsk: Słowo/obraz terytoria.

Yoon, J. (2010). Spirituality in Contemporary Art. The idea of the Numinous. London: Zidane Press.

Agnieszka Tes - art historian and critic, painter, author of several dozen articles concerning contemporary art. Editor of a cultural journal Fragile. Currently she is $\mathrm{PhD}$ candidate in cultural studies in the Faculty of Philosophy at the Jesuit University Ignatianum in Krakow. She prepares her dissertation on spirituality in contemporary Polish abstract painting. 
